\title{
扇状地河川金川の河床変動特性と主流路の安定化 \\ Characteristics of River Bed Variation of the Kane River and Stabilization of Its Main Flow Channel
}

\author{
砂田 憲吾* - 京ケ島昭彦** 村瀬 孝*** \\ By Kengo SUNADA, Akihiko KYOGASHIMA and Takashi MURASE
}

\begin{abstract}
Characteristics of river bed variation of the Kane River, which is a typical alluvial river, are discussed by using a large scale hydraulic mode1. The results show that the flow patterns and the river bed configurations for all cases of flood discharges are very disorderly. In order to get a better way of the stabilization of the main flow channe1, some sets of layout of spur dikes are examined, and a new index is defined for quantitative evaluation of the channel stability. The index shows good agreement with the result of comprehensive observation of the river bed configurations.
\end{abstract}

Keywords: alluvial river, river bed variation, channel control, spur dike, experiment

\section{1.はじめに}

流域の開発や河川環境整備の気運の高まりにつれて、河川はより安全で楽しみやすい計画と管理が求めら れるようになってきている。いうまでもなく、河道の計画や河川環境の整備は個々の河川の特性に応じた形 で進められる必要がある。特に流路の变動が顕著な傾向をもつ扇状地河川では、現地河道特性の十分な理解 が不可欠である。著者らはこの点に関して、富士川水系の金川において今後の河道計画策定のための基礎資 料を得るために、移動床水理模型実験を実施してきている ${ }^{12}{ }^{2)}$ 。本稿では金川の現況河道での河床変動特性 および計画を水制方式とする場合を中心に、主流路の安定化を図るための系統的な実験を行うとともに、新 たに定義される流路偏倚指標を用いて主流路の安定性の評価を試みたのでその結果を報告する。

\section{2. 金川の概要と実験条件}

金川は幹線流路延長 $14.55 \mathrm{~km}$ 、流域面積 $56.5 \mathrm{~km}$ をもつ甲府盆地の東部を流れる富士川水系笛吹川の左支川 である。御坂山地にもつ水源より流路延長約 $8 \mathrm{~km}$ 地点で扇状地にでる。金川扇状地の頂角は約 $50^{\circ}$ 、半径は 約 $6 \mathrm{~km}$ であり、標高 $500 \mathrm{~m}$ 付近より笛吹川合流部の標高 $270 \mathrm{~m}$ に到っている。金川はこの扇状地のほぼ中央 を流れており、合流部付近下流域 $5 \mathrm{~km}$ の河床勾配は $1 / 25 \sim 1 / 180$ である。護岸は練石張りで、河道内は上流 部の木本植生の一部区間を除いて 1 年草〜多年草が繁茂している。瀬切れもしばしば発生する一方、出水時

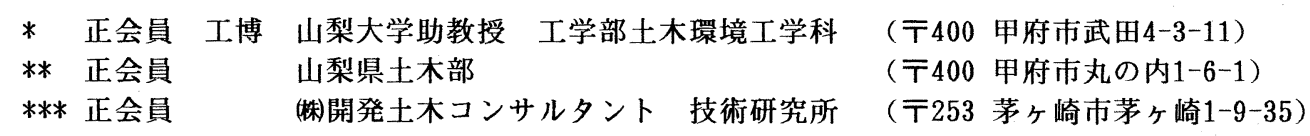


には流路・河床の変動が激

しい。

金川4.5kから1.5kまでの

$3 \mathrm{~km}$ 区間を対象として模型 河道には縮率 $1 / 50$ の無歪移 動床を用いた（平均河床勾 配 $1 / 31 ） 。$ 図一 1 に平面図 を示す。図に示すように両 岸には自然高水敷が形成さ

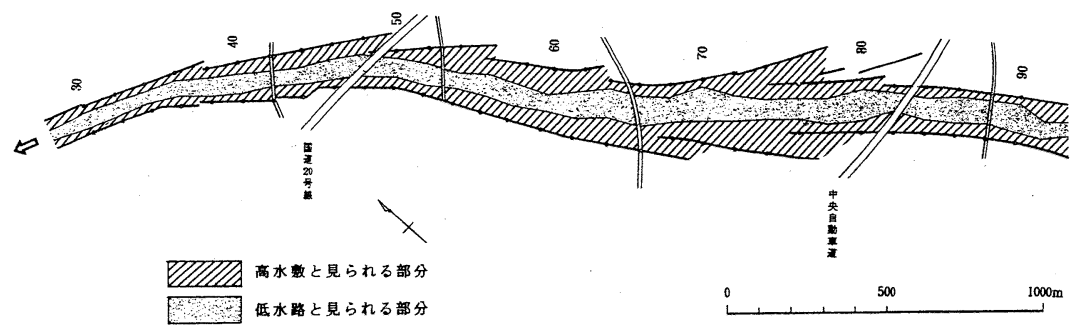
れており、模型では高水敷

図-1金川模型実験対象区間

及び低水路を平坦とした複断面河道に整形した。

現地河床材料のうち粒径 $3 \mathrm{~mm}$ 以下は浮遊砂之考えられ $ろ^{3)}$ ので、河床材料としては粒径 $3 \mathrm{~mm}$ 以下を除き混合砂

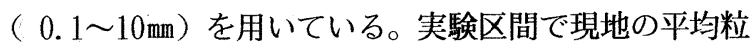
径は $17 \mathrm{~cm} \sim 5 \mathrm{~cm}$ と変化するが、ここでは中間点での粒径 分布に基ついて上のように混合砂を調整した。

流量は昭和58年 8 月出水時の雨量資料をもとに合理式 による最大流量との比で拡大した波形を基準に与えた。

通水実験中には上流部の河床低下が進行する。そこで、

\begin{tabular}{|c|c|c|c|c|c|c|}
\hline 記 & 号 & $\begin{array}{r}\text { 洪 } \\
\mathrm{Q}\end{array}$ & $\begin{array}{l}\text { 流 量 } \\
\left(\mathrm{m}^{3} / \mathrm{s}\right)\end{array}$ & 確率規模 & $\begin{array}{l}\text { 洪 水 時間 } \\
t_{P} \text { (hour) }\end{array}$ & 波 \\
\hline \multirow{3}{*}{ I } & 1 & ピーク & 310 & 5 年 & 71 & \multirow{3}{*}{ 不定流 } \\
\hline & 2 & ピーク & 550 & 50 年 & 71 & \\
\hline & 3 & ピーク & 620 & 100 年 & 71 & \\
\hline II & 1 & 一 定 & 310 & 5 年 & 30 & 定 \\
\hline III & 1 & ピーク & 620 & 100 年 & 71 & 不定流 \\
\hline
\end{tabular}

上流端では芦田・高橋・水山の式 ${ }^{4)}$ による平衡流砂量を

給砂している。

実験ケースは表 -1 に示 す通りである。

\section{3. 現況の河床変動特性}

（3.1）流況と平面的な 流路変化

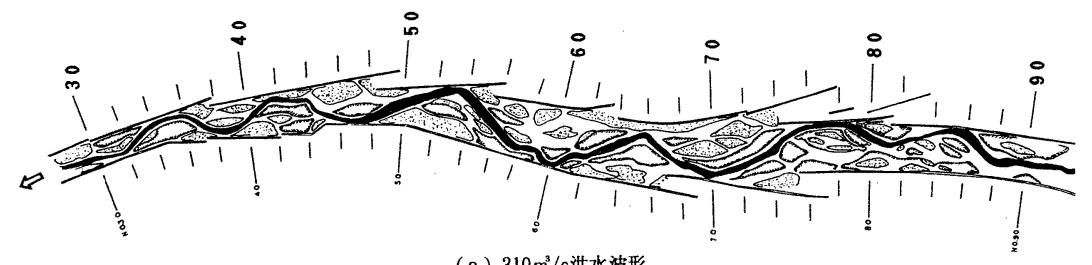

（a） $310 \mathrm{~m}^{3} / \mathrm{s}$ 洪水波形

通水後の河床状況は図一 2 のようである。河道は測 点70 60断面間が反向区間 であるため、この間の右岸 側における土砂堆積が大き い。このため流れは左岸側 へ大きく蛇行し左岸本堤ま で至り、再び右岸へ蛇行す る。本堤への水衝部では流 砂を伴った激しい流況を呈 する。

各流量とも網状の流れを 示すが、流量の増大ととも にみお筋はより太く、流れ は直進性をもつようになる。

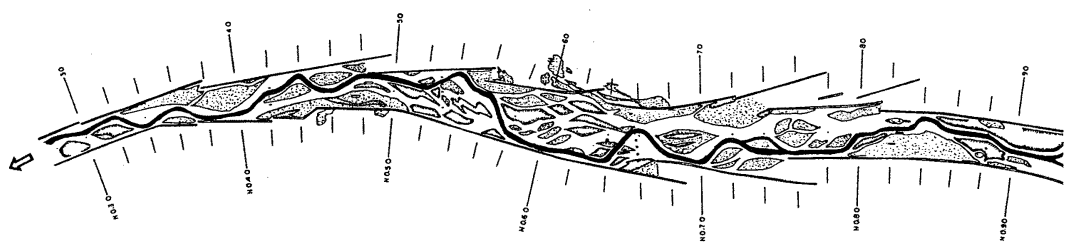

（b） $550 \mathrm{~m}^{3} / \mathrm{s}$ 洪水波形

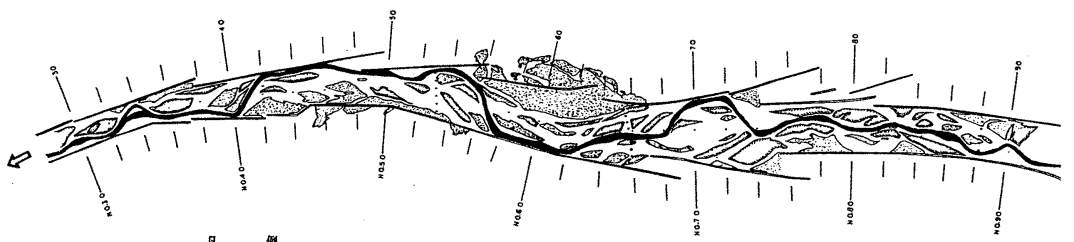

（c） $620 \mathrm{~m}^{3} / \mathrm{s}$ 洪水波形

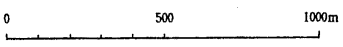

図-2 通水後の河床状況 


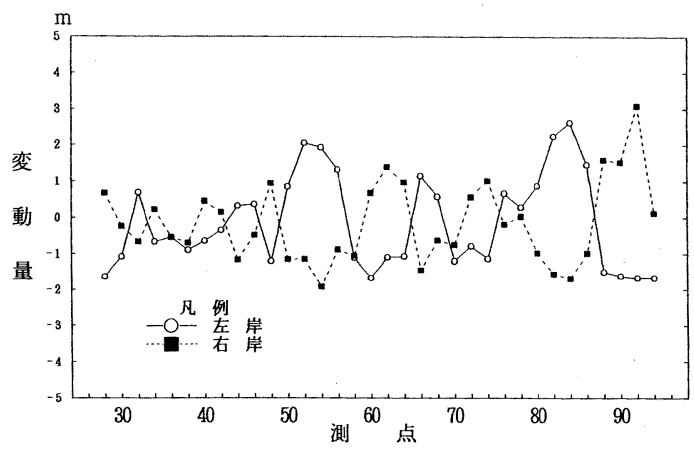

図- 3 縦断面形状 $\left(310 \mathrm{~m}^{3} / \mathrm{s}\right)$

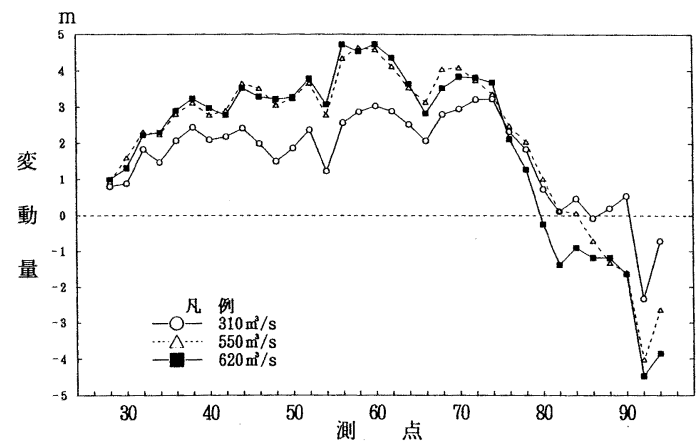

図-5平均河床高の変動量

（3.2）河道内蛇行モード

河道内河床変動は図- 3,4 に示すように左右岸 に沿う河床高が高くなったり低くなったり交番する。 その節となる間隔は流量が多くなるに従って長くな ることがわかる。

（3.3）平均河床変動之深掘れ

平均河床高の変動は図－5に示され、同図から 5 年確率流量と 50 ～100年確率流量のパターンに分類 できそうである。50年と 100 年確率流量の河床変動 は酷似しており 5 年確率流量の概ね 1.5 倍前後の変 動である。一方、図一6に示される深掘れ量につい ては流量の規模による格差は見られず、概ね $1 〜 2$ mの変動となっている。

（3.4）局所水理量と平均水理量

各断面における通水後断面を用いて得られる平均水理量と通水中 に計測した水面こう配、流速により近似的に計算される局所水理量 之を比較した。その一例として50年確率流量におりる無次元掃流力 の比較値を図一 7 に示す。同図に示すように局所水理量が平均水理 量の 4 倍ほど大きくなる箇所があることがわかる。

\section{4. 水制工（横工）方式による主流路の安定化}

不透過・非越流とする水制工（横工）方式による主流路の安定化 について、予備的な直線水路および現地模型水路で検討した。
表 -2 実験ヶース（直線水路）

\begin{tabular}{|c|c|c|}
\hline 実験番号 & ピーク流量 & 水 制 長 \\
\hline (1) & $310 \mathrm{~m}^{2} / \mathrm{s}$ & 水制なし \\
\hline (2) & $550 \mathrm{~m}^{3} / \mathrm{s}$ & " \\
\hline (3) & $310 \mathrm{~m}^{3} / \mathrm{s}$ & $(1 / 4) \mathrm{B}$ \\
\hline (4) & $550 \mathrm{~m}^{3} / \mathrm{s}$ & " \\
\hline (5) & $310 \mathrm{~m}^{3} / \mathrm{s}$ & $(1 / 6) \mathrm{B}$ \\
\hline (6) & $550 \mathrm{~m}^{3} / \mathrm{s}$ & $\prime \prime$ \\
\hline
\end{tabular}




\section{(4.1) 実験条件}

直線水路は、長さ $10 \mathrm{~m} 、$ 幅 $60 \mathrm{~cm}$ 一定の長方形断面開水路で、勾配 は $1 / 31 て ゙ 一$ 定とし、後述する金川での模型実験条件に準じて予備実 験を行った。横工水制の長さを左右各 $\ell=10 \mathrm{~cm}$ (河幅 $\mathrm{B}$ との比 $\ell / \mathrm{B}$ $=1 / 6)$ 及び $15 \mathrm{~cm} （ \ell / \mathrm{B}=1 / 4)$ を検討し（いずれも水制間隔は $60 \mathrm{~cm} ） 、$ 水制なしの場合と比較した。実験は表－ 2 に示す 6 通りである。

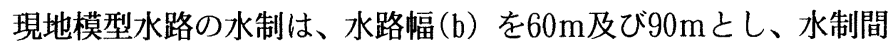
隔 $(\mathrm{L})$ を $100 \mathrm{~m}$ 及び $200 \mathrm{~m}$ とた。河床は全て平坦とする同一条件 である。流量は昭和58年 8 月出水時の雨量資料をもとに合理式によ る最大流量（ 5 年及び 50 年確率）との比で拡大した波形を与えた。

表 -3 実験ケース（現地模型水路）

\begin{tabular}{|c|c|c|c|}
\hline 実験番号 & 水路蝠 & 水制間隔 & ピーク流量 \\
\hline 1 & \multirow{4}{*}{$60 \mathrm{~m}$} & \multirow{2}{*}{$200 \mathrm{~m}$} & $310 \mathrm{~m}^{3} / \mathrm{s}$ \\
\hline 2 & & & $550 \mathrm{~m}^{3} / \mathrm{s}$ \\
\hline 3 & & \multirow{2}{*}{$100 \mathrm{~m}$} & $310 \mathrm{~m}^{3} / \mathrm{s}$ \\
\hline 4 & & & $550 \mathrm{~m}^{3} / \mathrm{s}$ \\
\hline 5 & \multirow{4}{*}{$90 \mathrm{~m}$} & \multirow{2}{*}{$200 \mathrm{~m}$} & $310 \mathrm{~m}^{3} / \mathrm{s}$ \\
\hline 6 & & & $550 \mathrm{~m}^{3} / \mathrm{s}$ \\
\hline 7 & & \multirow{2}{*}{$100 \mathrm{~m}$} & $310 \mathrm{~m}^{3} / \mathrm{s}$ \\
\hline 8 & & & $550 \mathrm{~m}^{3} / \mathrm{s}$ \\
\hline
\end{tabular}
実験ケースを表一 3 に示す。

\section{（4.2）流路偏倚指標}

河床横断面の形状を定量的に評価するために以下 のような指標を考える。

河道中心から右岸方向の距離を $\mathrm{x}$ とし、その位置

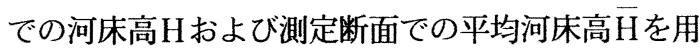
いて、 $\eta=\mathrm{H}-\overline{\mathrm{H}}$ より $\eta$ を求める。河幅を $\mathrm{B}$ とし てB/2 を用いて無次元化し、 $\widetilde{x}=\mathrm{x} /(\mathrm{B} / 2) 、 \widetilde{\eta}=\eta$ /(B/2) と表し、次の一次モーメントで流路偏倚指標 を定義する。

$$
\begin{aligned}
& \mathrm{G}_{\mathrm{u}}=\int_{-1}^{1}|\widetilde{\mathrm{x}}| \cdot \widetilde{\eta} \cdot \mathrm{d} \widetilde{\mathrm{x}} \quad(\widetilde{\eta}>0) \\
& \mathrm{G}_{\mathrm{D}}=\int_{-1}^{1}|\widetilde{\mathrm{x}}| \cdot \widetilde{\eta} \cdot \mathrm{d} \widetilde{\mathrm{x}} \quad(\widetilde{\eta}<0) \\
& \mathrm{G}=\mathrm{G}_{\mathrm{u}}+\mathrm{G}_{\mathrm{D}}
\end{aligned}
$$

典型的な横断面形状パターンに対する $G_{v}, G_{D}$ の 相対的な大小関係を例示すれば図－8のようになる。 タイプ I 〜VII次の予備実験の結果に対応している。

（4.3）主流路の安定化 I（直線水路の場合）

直線水路で予備的な 6 尖験を行った結果、流路偏 倚指標の分類として図-9に示すように 7 形態（視 察により I〜VII）に分けることができる。たとえば、 原点から遠いほど横断面の変化は激しく、右下の夕 イプ I〜IIIは河心で低河床となることを示す。特に、 極端な洗掘も少ない夕イプIすなわち $\triangle$ 印、×印の 条件では治水上の観点から良好な結果が得られる形 であり、水制なしの場合に比較して水制設置の場合 に着実に改善されている。流路偏倚指標を用いるこ とによって河床形状の定量評価が可能と考えられる。

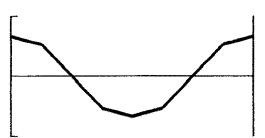

凹型断面 $\mathrm{G}_{\mathrm{U}}>\left|\mathrm{G}_{\mathrm{D}}\right|$ $\therefore \mathrm{G}>0$ : I, II, III

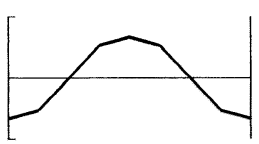

凸型断面 $\mathrm{G}_{\mathbf{U}}<\left|\mathrm{G}_{\mathbf{D}}\right|$ $\therefore \mathrm{G}<0 \quad: \mathrm{VI}, \mathrm{VII}$

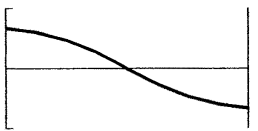

$\begin{aligned} \mathrm{G}_{\mathrm{u}} & \fallingdotseq\left|\mathrm{G}_{\mathrm{D}}\right|=\text { 大 } \\ \therefore \mathrm{G} \fallingdotseq 0 & =\mathrm{V}\end{aligned}$

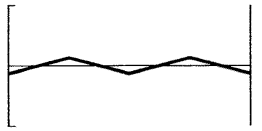

$\mathrm{G}_{\mathrm{u}} \fallingdotseq\left|\mathrm{G}_{\mathrm{D}}\right|=$ 小 $: \mathrm{IV}$

図-8 流路偏倚指標

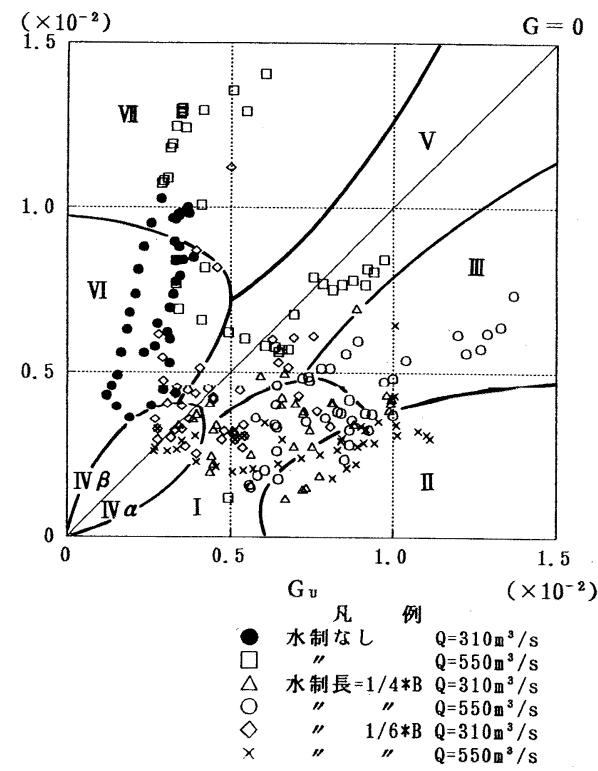

図-9流路偏倚指標の領域分類（直線水路） 
（4.4）主流路の安定化II（現地模型水路の場合）

水路幅 $90 \mathrm{~m}$ における流況 の例を図一10に示す。これ らのうち、水制間隔 $100 \mathrm{~m}$ 、 5 年確率程度の流量 $\left(310 \mathrm{~m}^{3}\right.$ /s）のケースの場合には水 制間に堆積した土砂の流出 は見られず、凹型断面の比 較的安定した主流路が形成 されるようである。

表一 3 に対応する全ての 実験ケースに対して通水後 の横断面形状から、各断面 の河幅で規格化した流路偏 倚指標を解析した。結果を 図一12〜13に示す。水制な しの場合を図一11に示す。

(1) $\mathrm{L}=200 \mathrm{~m}$ の場合 $\mathrm{b}=90 \mathrm{~m} 、 60 \mathrm{~m}$ ともに流量 2 ケースの場合とも指標は 負の領域に多く分布し、側 岸部に深掘れが生ずる傾向 を示す。

(2) $\mathrm{L}=100 \mathrm{~m}$ の場合 $\mathrm{b}=90 \mathrm{~m} 、 60 \mathrm{~m}$ ともに流量 2 ケースの場合とも小さい 值で分布するが、より安定

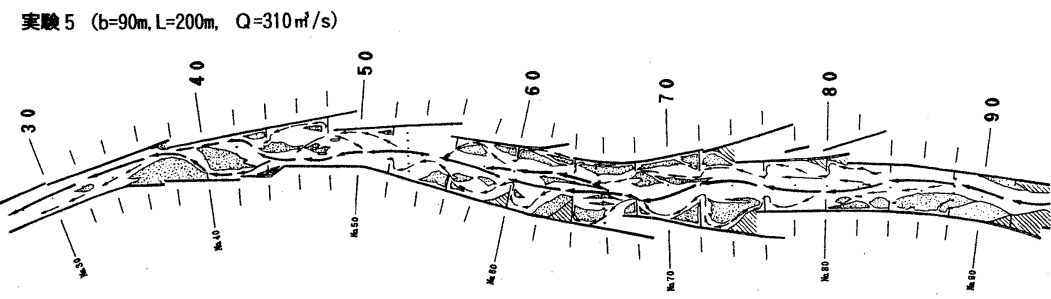

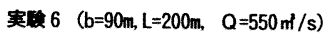

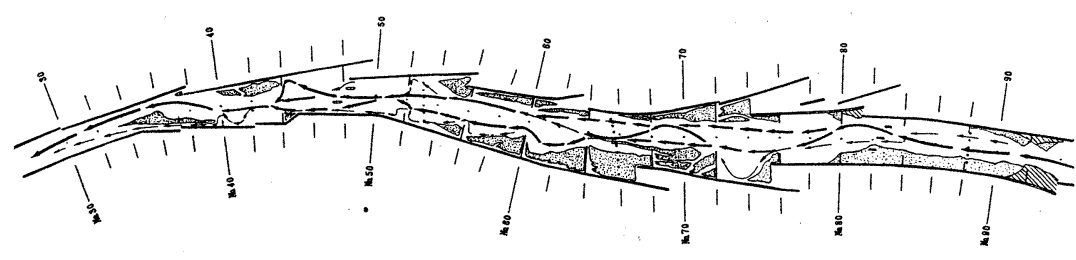

英期 $7\left(b=90 \mathrm{~m}, \mathrm{~L}=100 \mathrm{~m}, \mathrm{Q}=310 \mathrm{~m}^{3} / \mathrm{s}\right)$

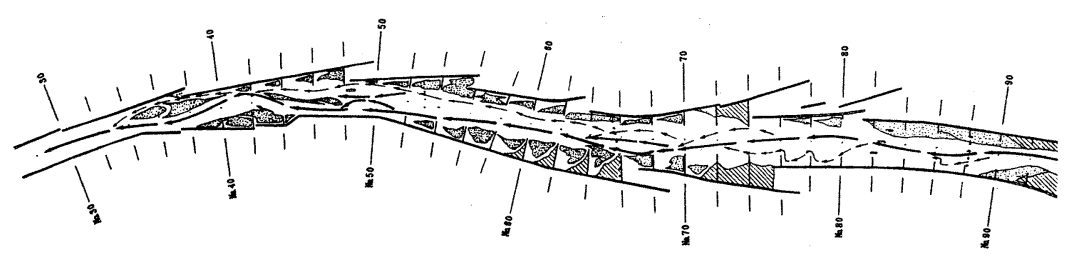

实政 $8(b=90 \mathrm{~m}, \mathrm{~L}=100 \mathrm{~m}, \mathrm{Q}=550 \mathrm{~m} / \mathrm{s})$
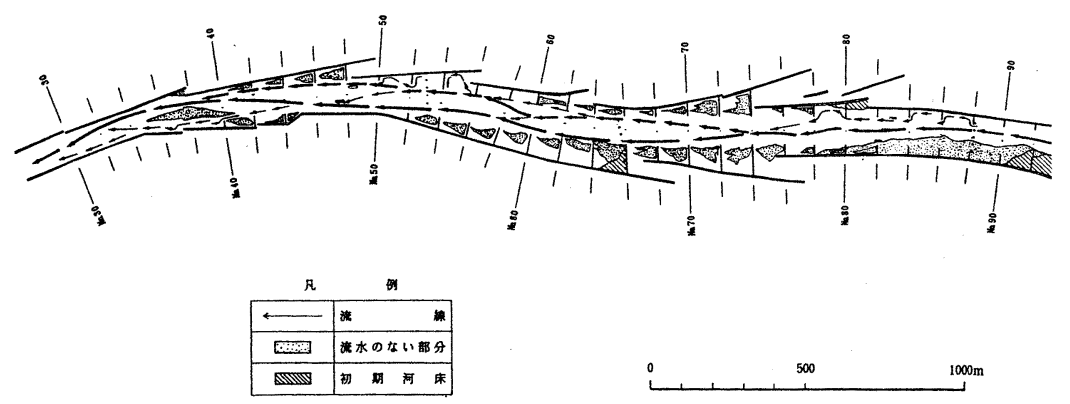

図 - 10 ピーク流量時の流況 $(b=90 m)$ した流路を示すようになる。 $\mathrm{b}=60 \mathrm{~m} 、 \mathrm{Q}=310 \mathrm{~m}^{3} / \mathrm{s}$ の場合 は、 $\mathrm{b}=90 \mathrm{~m}$ とする場合と比 較して偏倚の幅は狭められ ることから、平坦河床の断 面から凹型断面への流路が発達しより安定的な流路が形成されると考えられる。

$550 \mathrm{~m}^{3} / \mathrm{s}$ にいては、掃流力が高まり直進性がさらに進むこととなり流路は河道中央に固定され、 $\mathrm{b}=90 \mathrm{~m}$ と する河道よりいっそう凹型断面が発達し、好都合になるものと考えられる。

\section{5. おわりに}

金川における現況河道における河床变動特性を知ると共にその主流路の安定化の方法を得るために実験的 検討を行った。

まず、現況河道の場合の実験結果から流況、水理量、河床変動ほかの検討を総合すると、金川は堆積、洗 掘域および砂州の状態など流れの集中、発散があり以下のような不安定な河道状況を呈することが知れた。

(1) 現状の河道特性の特徴は測点70断面から測点40断面程度までは堆積傾向にある。よくに反向区間であ 


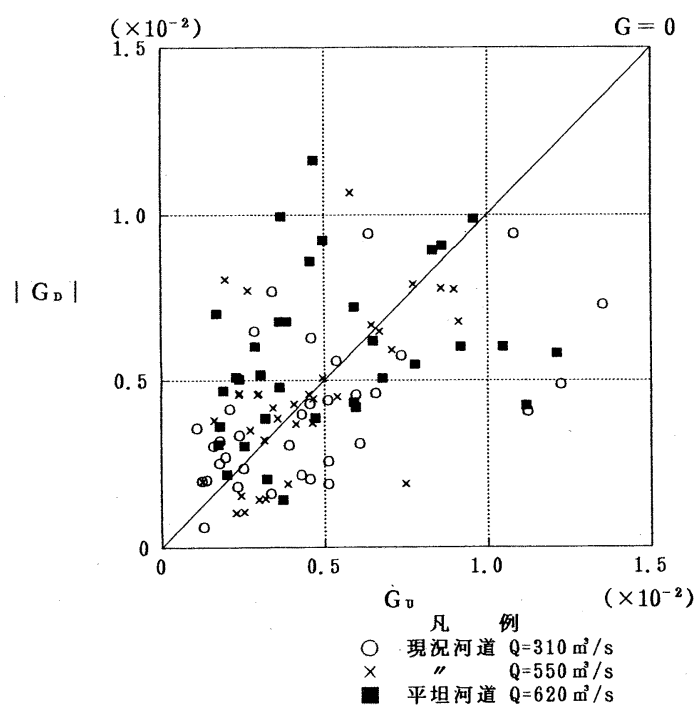

図-11 流路偏倚指標分布図（現地模型水路・水制なし）

り漸拡河道部である测点70〜60断面間に堆積、 湓水の特徴的な傾向がある。

（2）大流量で河道内蛇行モードが大きくなり、 高水敷の浸食を伴い水衝部が固定するなどの 激しい流況を呈する。

（3）また流量規模の必ずしも大きくない流量で あっても、出水の繰り返しにより激しい河床 変動が生ずる可能性がある。

（4）各断面の水理量の测定結果から平均量、局 所量の差が大きく局所的に 4 倍程度の值とな る場合があり局所洗掘、深掘れが起きる可能 性を有している。

続いて、金川の主流部の安定化のために横工水 制工方式を用いる場合について、直線水路及び現 地模型水路を用いて実験的に検討した。その結果、

（5）水路幅を $60 \mathrm{~m}$ とし、水制間隔を $100 \mathrm{~m}$ とす る場合が最も効果があがり流路が安定的に河 川の中央に固定されることが明らかとなった。

（6）新たに定義された流路偏倚指標によれば、河床形状を定量的に数值で表すことができる。この指標に より治水上効果的な主流路安定化案の客観的な抽出が可能となる。

などが得られた。今後も検討を重ねてゆきたいと考えている。

\section{[弆考文献]}

1) 村瀬 孝・京ヶ島昭彦・砂田憲吾 : 扇状河川金川（富士川水系）の河床変動特性, 土木学会第48回年講概 要集 II, pp530 531, 1993年 9月.

2)村瀬 孝・京ヶ島昭彦・砂田憲吾：急流河川における主流路の安定化とその評価法について，土木学会第 49回年講概要集 II, pp546〜 547, 1994年 9月.

3 )山本晃一亳橋晃: 河川水理模型実験の手引, 土木研究所資料, 2803,1989 年10月.

4)芦田和男・高橋保・水山高久：山地河川の掃流砂量に関する研究, 新砂防, 107, pp9-17, 1978年 4月.

5)砂田憲吾 : 河川中流部における土砂の諸問題(1)，(2)，新砂防, 167, 168, pp4-10, pp54-59, 1990年 3,4月. 